\title{
EFFECTS OF BORON APPLICATION AND GAMMA RAY IRRADIATION ON YIELD OF SUGAR BEET (BETA VULGARIS L.) GROWN IN SANDY SOIL
}

\author{
Ahmed A Moursy* AND MM IsmaIL \\ Soils and Water Research Department, Nuclear Research Center, \\ Atomic Energy Authority, Egypt. P.O 13759.
}

Keywords: Sugar beet, Boron, Irradiation, Sucrose, Yield, Nutrients

\begin{abstract}
Effects of boron as an essential nutrient for sugar beet along with gamma irradiation was traced under field conditions. Data demonstrated that the fresh and dry root yields of sugar beet significantly increased with the increase either gamma dose or boron levels comparing to the non-irradiated and born-untreated plants. It seems that root dry weight tended to increase gradually with increasing gamma dose 0 to $100 \mathrm{~Gy}$, then tended to decrease with 200 Gy dose but it still increased with gradual increases of boron levels. In this regard, the best value of root dry weight was achieved with $100 \mathrm{~Gy}$ dose interacted with $2.40 \mathrm{~kg} / \mathrm{ha}$ of boron addition. On the other hand, plants exposed to $50 \mathrm{~Gy}$ and treated with $2.40 \mathrm{~kg} / \mathrm{ha}$ reflected the highest shoot dry matter yield compared to other treatments. Relatively, this treatment increased shoot dry weight by about one fold, two folds and near to two folds for the same sequence. Behavior of NPK uptake by shoots has the same trend. Plants irradiated with $100 \mathrm{~Gy}$ together with $2.40 \mathrm{~kg}$ boric acid ha ${ }^{-1}$ yielded the highest total soluble solids (TSS\%) and produced the best per cent of sucrose.
\end{abstract}

\section{Introduction}

Sugar beet (Beta vulgaris L.) is the second crop for sugar production in Egypt next to sugar cane. The production of sugar beet in Egypt has been expanded vertically and horizontally to a great extent through the period from 1982 to 2016 (Abd El-Hady 2017). All sugar beet genotypes of Beta vulgaris cultivated in Egypt are imported from foreign countries. So, it is preferable to evaluate them under Egyptian conditions especially under newly reclaimed soils to select the best suited ones (Hozayn 2013). Its productivity increased from 1.0 to 2.5 ton sugar/fad and its area from about 17 thousands to more than 545 thousands faddan in the same period.

Irradiation is an ionic, no-heat process that continues to receive attention as a preservation and functional modification agent in polymer research and application (Abu et al 2006). Nuclear techniques, in contrast to conventional breeding techniques, are widely applied in agriculture for improving genetically diversity. Unlike conventional breeding procedures which involve the production of new genetic combinations from already existing parental genes, nuclear technology causes exclusively new gene combinations with high mutation frequency. Basic tool of nuclear technology for crop improvement is the use of ionizing radiation which causes induced mutations in plants. These mutations might be beneficial and have higher economical values (Abdul et al. 2010).

Boron plays an important role in the growth and productivity of many crops, especially sugar beet crop, which helps to accelerate the sugar translocation process. Allen and Pilbeam (2007) emphasized that sugar beet crop has high requirements for boron when adequate boron nutrition is critical for high yield and quality of crops. They also reported that boron increases the rate of transport of sugars from source to sink. Abido (2012) reported that the advantage of boron application might be due to the function of boron in increasing plant metabolism, development and

*Author for correspondence: <ahmad1a2m3@yahoo.com>. 
growth. El-Geddawy and Makhlouf (2015) found that there was a significant positive increase in root diameter and root length of sugar beet due to the gradual increase in the spraying concentration of boron from 105 to $210 \mathrm{mg} / \mathrm{l}$. In addition, as reviewed by Abid et al. (2019), boron is considered as one of the seven essential micronutrients required for the normal growth of most of the cereal, fruit and vegetable crops. It also influences cell development and elongation (Bennett 1993). Boron affects carbohydrates metabolism and plays a role in amino acid formation and synthesis of proteins (Tisdale et al. 1985). Deficiency of boron can also cause reduction in crop yield and inferior crop quality. Therefore, the present study aimed to investigate the productivity and quality of sugar beet yield and its contents of total soluble solids (T.SS \%) as well as sucrose $\%$, influenced by the applications of gamma ray doses as well as various boron fertilizer levels and their interaction on fresh and dry root yield of sugar beet.

\section{Materials and Methods}

An open field experiment was carried out at the farm of Soil and Water Research Dept., Nuclear Research Center, Atomic Energy Authority, Inshas, Egypt. Site is located $35 \mathrm{~km}$ to the north of Cairo capital with $30^{\circ} 24^{\circ} \mathrm{N}$ latitude, $31^{\circ} 35^{\circ} \mathrm{E}$ longitude, while the altitude is $20 \mathrm{~m}$ above the sea level. The experimental soil was classified as sandy textured soil. Sugar beet was sown on 31 October during the winter season of 2017. Surface soil sample $(0-15 \mathrm{~cm})$ was collected before sowing and prepared for some physical and chemical analyses (Table 1).

Table 1. Some physical and chemical properties of the experimental Sandy soil.

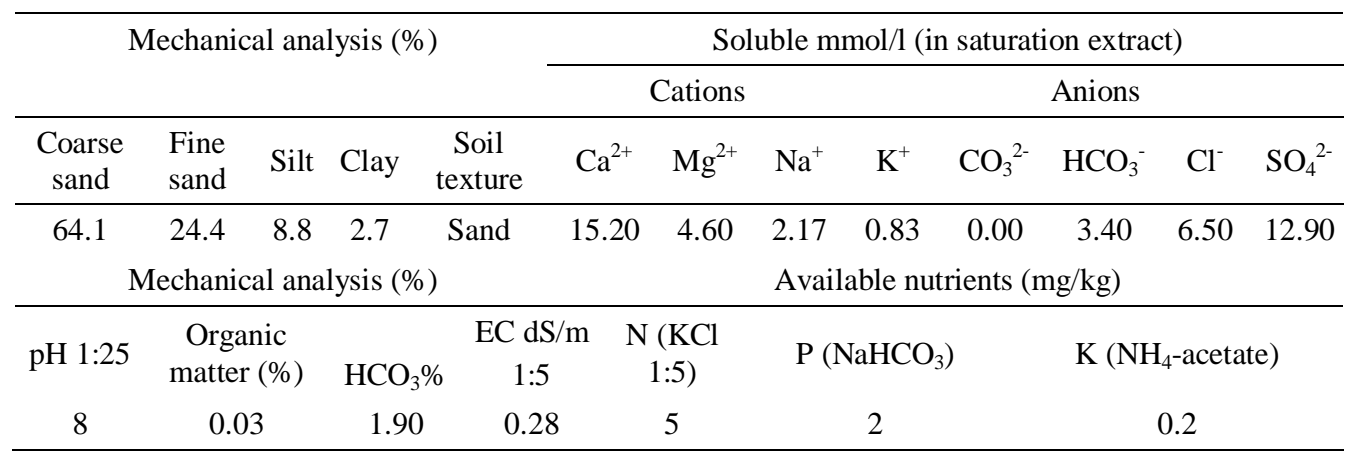

Sugar beet (Beta vulgaris) was provided by the Field Sugar Research Institute, Agricultural Research Center, Giza, Egypt. A batch of dry seeds were exposed to different doses of gamma irradiation $(0,50,100$ and $200 \mathrm{~Gy})$, using gamma rays generated from the Cobalt- 60 source in the Irradiation Laboratory at Cyclotron Department, Nuclear Research Center, Atomic Energy Authority ,Egypt. The experiment (two factors) was laid out in randomized complete block design with three replicates in plots with area $\left(1.5 \times 18 \mathrm{~m}^{2}\right.$ each one). Each plot having 3 rows, $50 \mathrm{~cm}$ row to row distance, Plots treated with Gamma rays 0, 50, 100 and $200 \mathrm{~Gy}$ and boron (as boric acid fertilization) with $0,1.20$ and $2.40 \mathrm{~kg} / \mathrm{ha}$ were applied. Soil was supplemented with nitrogen fertilizer at rate $192 \mathrm{~kg} \mathrm{~N} / \mathrm{ha}$ in the form of labeled ammonium sulphate $(21 \% \mathrm{~N})$ enriched with $2 \%{ }^{15} \mathrm{~N}$ atom excess and splitted into three equal doses, the $1^{\text {st }}$ one was applied after 30 days from sowing and the other two splits were later applied with two weeks interval for each split. Potassium sulphate at rate $50 \mathrm{~kg}$ as $\mathrm{K}_{2} \mathrm{O} 5$ was added two times in conjunction with the first and second splits of $\mathrm{N}$ fertilizer. Calcium super phosphate (15.5\%) was applied at $480 \mathrm{~kg} \mathrm{P}_{2} \mathrm{O}_{5}$ /ha during soil preparation. 
Chemical and physical analysis of tested soil samples was carried out according to (Page et al. 1982) and (Cottonie et al. 1982). Plant analysis for macro-elements, NPK was carried out according to Estefan et al. (2013). Sucrose (\%) was determined using Sacharimeter apparatus according to the method described by Le-Docte (1927), also total soluble solids (TSS\%) by using Hand Refractometer. The obtained results were subjected to ANNOVA analysis following SAS software program (1982) and the least significant difference was estimated at $\mathrm{p} \leq 0.05$.

\section{Results and Discussion}

Both of gamma ray doses and boric acid levels created a positive significant effect on fresh and dry root yields of sugar beet (Table 2). In case of irradiated seeds, fresh and dry root yield significantly $(\mathrm{p}>0.05)$ increased due to the interaction between boric acid levels and gamma ray doses. Mean values of fresh weight of roots as affected by gamma ray were $25.557,34.683$, 39.740 and 32.203 ton/ha in the plot received non-irradiation, 50, 100 and $200 \mathrm{~Gy}$, respectively were recorded. Relatively, 100 Gy dose resulted in an increase of fresh weight by about $14.58 \%$ over the non-irradiation treatment. Individual application of boric acid at the rate of $2.40 \mathrm{~kg} / \mathrm{ha}$ resulted in the highest values of fresh and dry root yield accounting for 33.50 and 11.17 ton/ ha, respectively. Those received $1.20 \mathrm{~kg}$ boric acid/ ha came ranked to the next. In this respect, the highest values mentioned above relatively increased by about 63 and $10 \%$ over the untreated control (boron 0) for rates 2.40 and $1.20 \mathrm{~kg}$ boric acid/ ha, respectively. This was true with either fresh or dry weight values. Concerning the interaction effect, the highest values of fresh and dry root yields were 41.67 ton/ha and 23.89 ton/ha, respectively. In the plot which received $2.40 \mathrm{~kg}$ boric acid/ha+ 100 Gy gamma rays, relatively increased by about 103.00 and $249.62 \%$ over the untreated control, respectively. Makhlouf and Khalil (2017) attributed the positive effect of boron to its role in root cell elongation. They also observed variations in effective root length between the treatments i.e. untreated control, Boric acid and Borax. On line, they cleared that in the control treatment the lowest values of root diameter $(14.5 \mathrm{~cm})$ and root fresh weight $(1076 \mathrm{~g} / \mathrm{plant})$ were recorded. Similarly, significant positive increase in root diameter and root length due to the gradual increase in the spraying concentration of boron from 105 to $210 \mathrm{mg} / 1$ was detected earlier (El-Geddawy and Makhlouf 2015) who found that spraying sugar beet foliage by $210 \mathrm{mg} \mathrm{l}^{-1}$ produced the highest averages of root thickness. Abido (2012) reported that the relative advantage of boron element on root thickness might be due to the distinct role on photosynthates translocation process. Gobarah and Mekki (2005) also found that boron application to sugar beet significantly increased root yield and its components as well as sugar yield.

Some studies explained the synergistic effect of gamma rays on plant growth and development by inducing cytological, biochemical, physiological and morphological changes in cells and tissues via producing free radicals in cells (Kim et al. 2004; Wi et al. 2005). The higher doses of gamma radiation were reported to be inhibitory (Radhadevi and Nayar, 1996; Kumari and Singh, 1996), whereas lower doses may be stimulatory. Low doses of gamma rays have been reported to increase cell proliferation, germination, cell growth, enzyme activity, stress resistance, and crop yields (Baek et al. 2005, Kim et al. 2005). In newly reclaimed sandy soil under drip irrigation system, application of boron in different forms and levels induced the highest values of root yield (34.63 ton/fad), top yield (7.773 ton/fad) in comparison to the untreated control. In the same time, significant variation between boron forms was detected. In addition, high levels of boron resulted in the highest values of sugar beet yield (Abd El-Hady 2017). Similarly, in Sand soil, Vincent (2010) declared that three different boron fertilizer levels increased average root weights, root yield, and per cent sugar content of roots. In fact, the boron treatments were so successful that larger root size and yield were easily seen at harvest. 
Table 2. Effect of gamma irradiation doses (Gy) and boric acid levels on fresh and dry root weights (ton/ha) of sugar beet.

\begin{tabular}{|c|c|c|c|c|c|c|c|c|}
\hline \multirow{4}{*}{$\begin{array}{l}\text { Gamma } \\
\text { irradiation } \\
\text { Gy }(\mathrm{R})\end{array}$} & \multicolumn{8}{|c|}{ Roots ( ton/ha) } \\
\hline & \multicolumn{4}{|c|}{ Dry weight } & \multicolumn{4}{|c|}{ Fresh weight (FW) } \\
\hline & \multicolumn{3}{|c|}{ Boric acid levels (kg/ha) } & \multirow{2}{*}{ Mean } & \multicolumn{3}{|c|}{ Boric acid levels (kg/ha) } & \multirow{2}{*}{ Mean } \\
\hline & 0 & 1.200 & 2.400 & & 0 & 1.200 & 2.400 & \\
\hline R0 & 6.833 & 7.557 & 11.167 & 8.519 & 20.500 & 22.670 & 33.500 & 25.557 \\
\hline $\mathrm{R} 50$ & 18.407 & 19.000 & 21.943 & 19.783 & 31.220 & 35.000 & 37.830 & 34.683 \\
\hline R100 & 22.590 & 23.260 & 23.890 & 23.247 & 37.770 & 39.780 & 41.670 & 39.740 \\
\hline R200 & 16.777 & 17.833 & 17.593 & 17.401 & 30.330 & 33.500 & 32.780 & 32.203 \\
\hline Mean & 16.152 & 16.913 & 18.648 & & 29.955 & 32.738 & 36.445 & \\
\hline \multirow{4}{*}{ LSD 0.05} & \multirow{2}{*}{\multicolumn{2}{|c|}{ Gamma dose (A) }} & DW & & \multicolumn{3}{|l|}{ FW } & \\
\hline & & & 0.949 & & 1.886 & & & \\
\hline & \multicolumn{2}{|c|}{ Boron (B) } & 0.571 & & 0.543 & & & \\
\hline & \multicolumn{2}{|l|}{$A \times B$} & 1.142 & & 1.886 & & & \\
\hline
\end{tabular}

Shoot dry yields of sugar beet significantly increased $(\mathrm{p}<0.05)$ due to seed irradiation and supply of different boric acid levels (Table 3). Likewise those of root, seed irradiation with $50 \mathrm{~Gy}$ induced an increase in shoot dry weight comparing to either the un-irradiated control or other irradiation doses. Relatively, on mean average base, this treatment increased shoot dry weight by about $61.8 \%$ over the un-irradiated treatment. In the same time, increasing levels of boric acid supply tended to increase shoot dry weight over those of un-treated control. In this respect, the highest value of shoot dry weight was detected with rate of $2.40 \mathrm{~kg}$ boric acid / ha, but both levels were nearly closed to each other. However, despite of irradiation doses, the mean average of dry shoot yields were $0.817,1.225$ and 1.247 ton/ha for $0,1.20$ and $2.40 \mathrm{~kg}$ boric acid/ha, respectively.

Table 3. Effect of gamma irradiation doses (Gy) and boric acid levels on top dry weights (ton/ ha) of sugar beet.

\begin{tabular}{|c|c|c|c|c|c|}
\hline \multirow{2}{*}{\multicolumn{2}{|c|}{ Gamma irradiation Gy (R) }} & \multicolumn{4}{|c|}{ Boric acid levels (kg/ha) } \\
\hline & & 0 & 1.20 & 2.40 & Mean \\
\hline R0 & & 0.667 & 1.000 & 0.867 & 0.845 \\
\hline $\mathrm{R} 50$ & & 0.600 & 1.667 & 1.833 & 1.367 \\
\hline R100 & & 1.000 & 1.220 & 1.222 & 1.147 \\
\hline R200 & & 1.000 & 1.011 & 1.067 & 1.026 \\
\hline \multirow{2}{*}{\multicolumn{2}{|c|}{ Mean }} & 0.817 & 1.225 & 1.247 & \\
\hline & & Gamma dose (A) & & 0.175 & \\
\hline \multirow{2}{*}{\multicolumn{2}{|c|}{ LSD 0.05}} & Boron (B) & & 0.105 & \\
\hline & & $A \times B$ & & 0.210 & \\
\hline
\end{tabular}

Supply with $2.40 \mathrm{~kg}$ boric acid/ha increased shoot dry weight by about $52.6 \%$ over the untreated (zero boric acid) control. From the above mentioned results it could be concluded that the best value of shoot dry weight (1.833 ton/ha) was achieved by application of $2.40 \mathrm{~kg}$ boric acid/ha 
combined with 50 Gy irradiation dose which relatively increased by about $174.8 \%$ over the untreated control ( $0.667 \mathrm{ton} / \mathrm{ha})$. Stimulatory effects of low gamma doses were observed at $150 \mathrm{~Gy}$ gamma irradiation, where the best results were obtained for seed germination percentage, and shoot growth initiation percentage, shoot and root lengths (Baek et al. 2005, Kim et al. 2005). Effect of boron supply was clarified by Abdel-Nasser and Ben Abdalla (2019) who found that all boron rates gave a significant increase in the shoot and root yields of sugar beet compared to the untreated plants. In this regard, application of $4.0 \mathrm{~kg}$ boric acid /fed was the best for achieving maximum fresh shoot and root yields compared to other boron treatments. Brown and $\mathrm{Hu}$ (1996) attributed the positive effect of boron to its role in cell elongation and turgidity where, in case of boron deficiency, plant leaves reported to be smaller, stiff and thick.

Non-irradiated (R0) plants reflected gradual increase in NPK uptake by roots due to raising the levels of boron supply (Table 4). Slight increases in NPK accumulation in roots occurred due to increase of boric acid levels when plants exposed to $50 \mathrm{~Gy}$ irradiation dose. In other turn, values of NPK as affected by B levels were nearly closed to each other. Similar trend, but to somewhat higher extent, was noticed with $100 \mathrm{~Gy}$ irradiation dose. Increasing irradiation dose up to $200 \mathrm{~Gy}$ inhibited the uptake of NPK by roots comparing to 100 and $50 \mathrm{~Gy}$ doses but still higher than those of the non-irradiated treatment. Comparison between irradiation treatments indicated the superiority of 100 Gy dose over 50 and 200 Gy. Difference between the effects of 50 and 100 Gy doses, in general, was not clear so much, therefore 50 Gy dose was recommended on the basis of economical view point (cost of gamma dose). The best treatment induced the reasonable amount of NPK in roots was the application of $2.40 \mathrm{~kg}$ boric acid / ha to plants exposed to $50 \mathrm{~Gy}$ irradiation dose. The high rate of boric acid enhanced vegetative growth and consequently absorption of other nutrients to meet the growth and production demand. According to, Mehran and Samad (2013) the contents of N and K in the roots of sugar beet significantly increased.

Table 4. Effect of gamma irradiation doses (Gy) and boric acid levels on $\mathrm{N}, \mathrm{P}$ and $\mathrm{K}$ in dry roots (kg/ ha) of sugar beet.

\begin{tabular}{|c|c|c|c|c|c|c|c|c|c|c|c|c|}
\hline \multirow{4}{*}{$\begin{array}{c}\text { Gamma } \\
\text { irradiation } \\
\text { Gy }(\mathrm{R})\end{array}$} & \multicolumn{9}{|c|}{$\mathrm{N}, \mathrm{P}$ and $\mathrm{K}(\mathrm{kg} / \mathrm{ha})$ in Dry Roots } & \multicolumn{3}{|c|}{$\begin{array}{l}\text { Mean of gamma } \\
\text { irradiation }\end{array}$} \\
\hline & \multicolumn{12}{|c|}{ Boric acid levels (kg/ha) } \\
\hline & \multicolumn{3}{|c|}{0} & \multicolumn{3}{|c|}{1.20} & \multicolumn{3}{|c|}{2.40} & 0 & 1.20 & 2.40 \\
\hline & $\mathrm{N}$ & $\mathrm{P}$ & K & $\mathrm{N}$ & $\mathrm{P}$ & $\mathrm{K}$ & $\mathrm{N}$ & $\mathrm{P}$ & $\mathrm{K}$ & $\mathrm{N}$ & $\mathrm{P}$ & $\mathrm{K}$ \\
\hline R0 & 63.5 & 50.9 & 71.5 & 67.0 & 53.5 & 81.8 & 92.5 & 65.7 & 90.7 & 74.3 & 56.7 & 81.3 \\
\hline R50 & 100.1 & 88.8 & 108.6 & 103.2 & 94.7 & 110.8 & 109.0 & 100.7 & 112.3 & 104.1 & 94.7 & 110.6 \\
\hline R100 & 109.5 & 103.6 & 109.8 & 114.0 & 104.2 & 114.3 & 115.4 & 106.5 & 106.5 & 113.0 & 104.8 & 110.2 \\
\hline $\mathrm{R} 200$ & 88.1 & 78.2 & 85.5 & 94.3 & 80.0 & 92.3 & 95.4 & 84.5 & 96.8 & 92.6 & 80.9 & 91.5 \\
\hline Mean & 90.3 & 80.4 & 93.9 & 94.6 & 83.1 & 99.8 & 103.1 & 89.4 & 101.7 & & & \\
\hline \multirow{4}{*}{ LSD 0.05} & \multirow{2}{*}{\multicolumn{3}{|c|}{ Gamma Rays (A) }} & \multicolumn{2}{|l|}{$\mathrm{N}$} & $\mathrm{P}$ & \multicolumn{2}{|r|}{ K } & & & & \\
\hline & & & & \multicolumn{2}{|c|}{2.010} & 2.106 & \multicolumn{2}{|c|}{2.905} & & & & \\
\hline & \multicolumn{3}{|c|}{ Boron (B) } & \multirow{2}{*}{\multicolumn{2}{|c|}{$\begin{array}{l}1.498 \\
2.998\end{array}$}} & 1.257 & \multicolumn{2}{|c|}{3.456} & & & & \\
\hline & \multicolumn{2}{|l|}{$\mathrm{A} \times \mathrm{B}$} & & & & 2.515 & & 911 & & & & \\
\hline
\end{tabular}

In comparison to boric acid, Qotob (2019) indicated that nano boron (B-NPs) had positive effect on all biological parameters and attributed this to sugar transport, cell membrane synthesis, nitrogen fixation, respiration, carbohydrate metabolisms, root growth, functional characteristics and development. 
Macronutrients uptake by the non-irradiated plants (R0) were not severely affected by sole application rates of boron (Table 5). Plants untreated with boron reflected an increase in $\mathrm{N}$ and $\mathrm{K}$ uptake by shoots with increasing gamma ray dose while P did not significantly vary. In this case, the best values of $\mathrm{N}$ and $\mathrm{K}$ uptake were achieved with exposure to $100 \mathrm{~Gy}$ dose followed by those of $200 \mathrm{~Gy}$ dose. Similar trends, but to somewhat higher extent, were noticed with interaction between boron levels and gamma ray doses. Generally, the highest values of N, P and K uptake by shoots were detected in plants irradiated with $100 \mathrm{~Gy}$ and treated with $2.400 \mathrm{~kg}$ boric acid / ha, which relatively increased by about $14.8,22.5$ and $16.3 \%$ for $\mathrm{N}$, and $\mathrm{K}$, respectively over the untreated control (zero boron). Concerning the effect of irradiation, these relative increases were 45.7, 30.5 and $43.8 \%$, respectively, for the same sequence over the non-irradiated plants (R0). Phosphorus concentration in grains of wheat plants increased significantly in response to combined application of increasing $\mathrm{P}$ and boron levels. Phosphorus uptake by grain, straw and total (grain + straw) increased significantly with the additional inputs of $\mathrm{P}$ and boron fertilizers (Irfan et al. 2019).

Table 5. Effect of gamma irradiation doses (Gy) and boric acid levels on N, P, K in dry shoots (kg/ ha) of sugar beet.

\begin{tabular}{|c|c|c|c|c|c|c|c|c|c|c|c|c|}
\hline \multirow{4}{*}{$\begin{array}{c}\text { Gamma } \\
\text { irradiation } \\
\text { Gy }(\mathrm{R})\end{array}$} & \multicolumn{9}{|c|}{$\mathrm{N}, \mathrm{P}$ and $\mathrm{K}(\mathrm{kg} / \mathrm{ha})$ in dry shoot } & \multicolumn{3}{|c|}{$\begin{array}{l}\text { Mean of gamma } \\
\text { irradiation }\end{array}$} \\
\hline & \multicolumn{12}{|c|}{ Boric acid levels (kg /ha) } \\
\hline & \multicolumn{3}{|c|}{0} & \multicolumn{3}{|c|}{1.20} & \multicolumn{3}{|c|}{2.40} & 0 & 1.20 & 2.40 \\
\hline & $\mathrm{N}$ & $\mathrm{P}$ & K & $\mathrm{N}$ & $\mathrm{P}$ & K & $\mathrm{N}$ & $\mathrm{P}$ & $\mathrm{K}$ & $\mathrm{N}$ & $\mathrm{P}$ & K \\
\hline R0 & 59.4 & 51.1 & 58.8 & 59.6 & 51.4 & 65.2 & 50.1 & 49.2 & 60.51 & 56.4 & 50.57 & 61.5 \\
\hline $\mathrm{R} 50$ & 50.2 & 46.8 & 57.7 & 63.9 & 53.9 & 55.9 & 66.6 & 52.9 & 67.8 & 60.2 & 57.8 & 60.5 \\
\hline R100 & 63.6 & 52.4 & 74.8 & 65.9 & 56.9 & 86.6 & 73.0 & 64.2 & 87.0 & 67.5 & 57.8 & 82.8 \\
\hline R200 & 59.8 & 49.9 & 63.28 & 61.0 & 50.7 & 77.2 & 61.6 & 51.8 & 78.6 & 60.8 & 50.8 & 73.0 \\
\hline Mean & 58.3 & 50.1 & 63.6 & 62.6 & 52.7 & 71.2 & 62.8 & 54.3 & 73.5 & & & \\
\hline \multirow{4}{*}{ LSD 0.05} & & \multicolumn{2}{|l|}{$\mathrm{N}$} & $\mathrm{P}$ & \multicolumn{2}{|c|}{$\mathrm{K}$} & & & & \\
\hline & \multicolumn{3}{|c|}{ Gamma Rays (A) } & \multicolumn{2}{|c|}{1.839} & 2.922 & \multicolumn{3}{|c|}{4.260} & & & \\
\hline & \multicolumn{3}{|c|}{ Boron (B) } & \multicolumn{2}{|c|}{1.507} & 2.248 & \multicolumn{3}{|c|}{1.842} & & & \\
\hline & \multicolumn{3}{|l|}{$A \times B$} & \multicolumn{2}{|c|}{3.015} & 4.498 & \multicolumn{3}{|c|}{3.248} & & & \\
\hline
\end{tabular}

Total soluble solids percentage (TSS \%) and sucrose percentage (sucrose \%), of sugar beet were significantly affected by the application of different rates of boric acid as well as gamma ray doses and their interaction up to rate of ( 2.40 ton/ ha boric acid and $200 \mathrm{~Gy}$ ) (Table 6). Despite of irradiation doses, the mean average of TSS \% (17.8\%) and sucrose \% (15.4\%) were the highest when sugar beet plants were treated with boric acid at rate $2.40 \mathrm{~kg} / \mathrm{ha}$. On the other hand, the lowest values of TSS $(15.2 \%)$ and sucrose $(13.3 \%)$ as mean average were recorded with untreated control. The mean average of TSS\% and sucrose $\%$ as affected by gamma dose, despite of boron treatments, tended to increase with increasing gamma dose. In this respect, the highest mean values were detected with plants exposed to 100 Gy gamma ray where as it was $19.4 \%$ and $15.2 \%$ for TSS and sucrose, respectively. Concerning the interaction effect, the highest values of TSS $(22.0 \%)$ and sucrose $(15.8 \%)$ were recorded in the plot which received $2.40 \mathrm{~kg}$ boric acid /ha + 100 Gy gamma rays. On line, El-Geddawy and Makhlouf (2015) found that increasing boron foliar application attained a significant response in the values of root fresh weight of sugar beet. 
They also reported that this observation is due to the important role of boron in dry matter translocation and accumulation which in turn was reflected on the final root fresh weight. They also investigated the effect of boron fertilizer levels on sucrose percentage in sugar beet roots and found that there was significant increase in the values of sucrose \% due to the increase in applied doses of boron fertilizer. Similarly, Abd El-Hady (2017) indicated that different forms of boron added at high levels resulted in the highest sugar yield (6.00 ton/fad), sucrose percentage (18.86\%) and extractable sugar percentage (17.33\%) which was recorded with Borfam (high level) treatment followed by Borfam (low level) treatment, comparing to boric acid and borax forms, while the lowest values were recorded with control treatment (without boron application). Allen and Pilbeam (2007) emphasized that sugar beet crop has high requirements for boron when adequate boron nutrition is critical for high yield and quality of crops. They also reported that boron increases the rate of transport of sugars from source to sink. Wang et al. (2015) reported that potassium $(\mathrm{K})$ is an essential nutrient required in higher amounts for plant metabolism especially for photosynthesis and assimilates transport. Similarly, Qotob et al. (2019) found that nano boron source (B-NPs) was more effective than boric acid for sucrose, purity, $\alpha$ - amino nitrogen and total soluble solids.

Table 6. Effect of gamma irradiation doses (Gy) and boric acid levels on percentages of TSS and Sucrose in root of sugar beet.

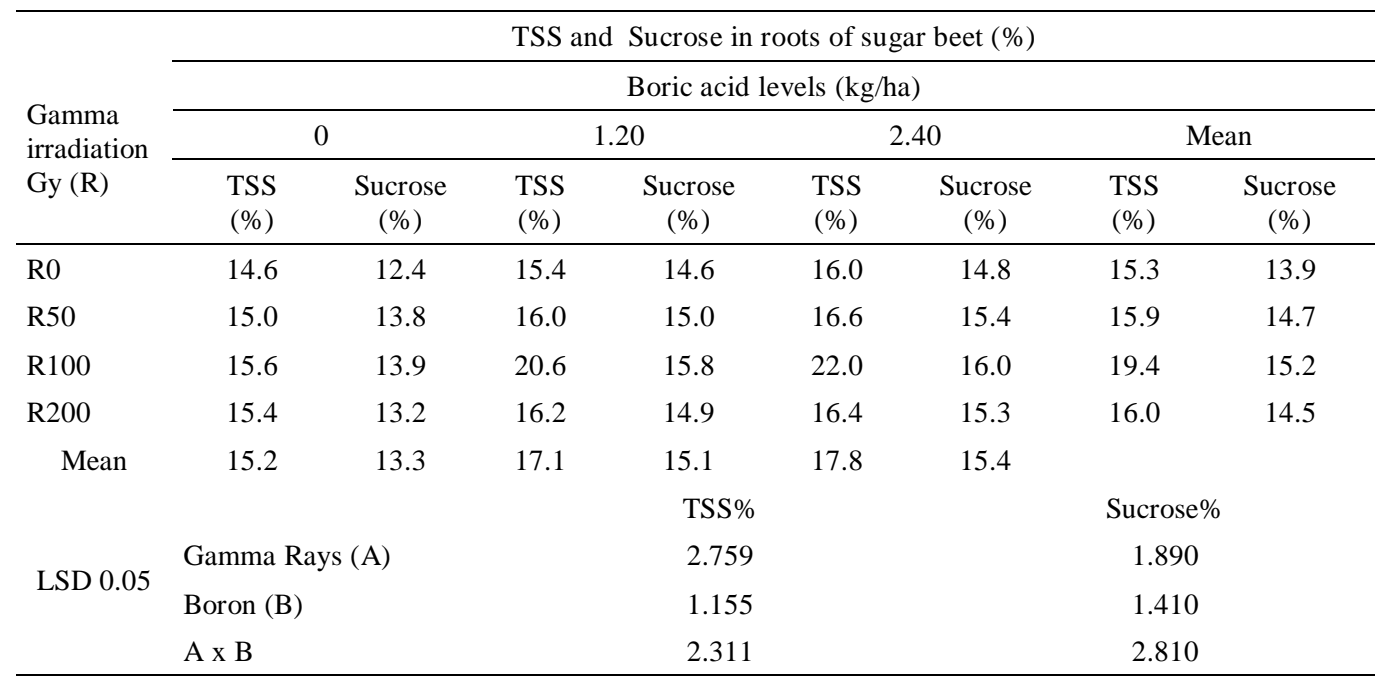

Based on the findings, it may be concluded that the application of boric acid as boron fertilizer source and exposure of sugar beet seeds to different gamma ray doses before sowing increases the quantity and quality of sugar beet grown on sandy soil. The root and sugar yields are among the most important in sugar beet production parameters. Under condition of low fertile sandy soil, the highest root and sugar yield were achieved by high rate of boric acid combined with $100 \mathrm{~Gy}$ gamma dose. It means that this dose of gamma ray have a synergistic effect on growth and yield of sugar beet roots. Similarly, addition of boric acid either solely or in combination with gamma doses resulted in the highest values of 17.8, 17.1, 15.2\% for TSS and 15.4, 15.1, 13.3\% for sucrose as affected by supply of boric acid at $2.40,1.20 \mathrm{~kg} / \mathrm{ha}$ and the untreated control, respectively. 


\section{References}

Abd El-Hady MA 2017. Response of sugar beet growth, productivity and quality to foliar application of different forms of boron microelement and number of sprays under new reclaimed soil conditions Egypt. J. Agron. 39(3): 401-410 .

Abdel-Nasser G and Ben Abdalla, Kh T 2019. Boron soil application and deficit irrigation in relation to sugar beet production under drip irrigation system. Int. Res. J. Applied Sci. 1(1): 17-29.

Abdul Majeed, Asif Ur Rehman Khan, Habib Ahmad, Zahir Muhammad 2010. Gamma irradiation effect on some growth parameters of Lepidium sativum L. ARPN, J. Agric. Biol. Sci. 5(1): 39-42.

Abid K Zafar H Asad Ali K Junaid A Md Waseem A Haq N Farhan A and Kaleem A 2019. Effect of foliar application of zinc and boron on growth and yield components of wheat. Agri Res \& Tech: Open Access J. 21(1): 556148. DOI: 10.19080/ARTOAJ.2019.21.556148

Abido WAE 2012. Sugar beet productivity as affected by foliar spraying with methanol and boron. Intern. J. Agric. Sci. 4(7): 287-292.

Abu, J.O., K.G. Duodu and A. Minnaar, 2006. Effect of $\gamma$-irradiation on some physicochemical and thermal properties of cowpea (Vigna unguiculata L. Walp) starch. Food Chemistry. 95(3): 386-393.

Allen V B. and Pilbeam, DJ (Ed) 2007. "Handbook of Plant Nutrition" (Books in Soils, Plants and the Environment). Boron by Umesh C. Gupta. pp. 241-278.

Baek MH, Kim JH, Chung BY, Kim JS and Lee IS 2005. Alleviation of salt stress by low dose g-irradiation in rice. Biol. Plant. 49 (2): 273e276.

Bennett WF 1993. Plant nutrient utilization and diagnostic plant symptoms. In: Benett WF (Ed.), Nutrient Deficiencies and Toxicities in Crop Plants, APS Press. St. Paul, M.H. p. 1-7.

Brown PH and H Hu 1996. Phloem mobility of boron is species dependent: Evidence for phloem mobility in sorhitolrich species. Ann. Bot. 77: 497-505.

Cottenie A M Verloo G. Velghe and R Cameriynck 1982. Chemical analysis of Plant and Soil Laboratory of Analytical and Agrochemistry, State Univ., Ghent, Belgium. 63p.

El-Geddawy Dalia IH and Makhlouf BSI 2015. Effect of hill spacing and nitrogen and boron fertilization levels on yield and quality attributes in sugar beet. Minufia J. Agric. Res. 4(1): 959-980.

Estefan, G., R. Sommer and J. Ryan. 2013. Methods of soil,plant and water analysis: A anual for the West Asia andNorth Africa Region. 3rd ed. ICARDA, Beirut, Lebanon.

Gobarah Mirvate E and Mekki BB 2005. Influence of boron application on yield and juice quality of some sugar beet cultivars grown under saline soil conditions. J. Appl. Sci. Res. 1(5): 373-379.

Hozayn M 2013. screening of some exotic sugar beet cultivars grown under newly reclaimed sandy soil for yield and sugar quality traits. J. Appl. Sci. Res., 9(3): 2213-2222.

Irfan M, Abbas M, Shah JA, Depar N, Memon MY and Sial NA 2019 . Interactive effect of phosphorus and boron on plant growth, nutrient accumulation and grain yield of wheat grown on calcareous soil. Eurasian J Soil Sci. 8(1): 17-26.

Kim JH, Baek MH, Chung BY, Wi SG and Kim JS 2004. Alterations in the photosynthetic pigments and antioxidant machineries of red pepper (Capsicum annuum L.) seedlings from gamma-irradiated seeds. J. Plant Biol. 47: 314e321.

Kim JH Chung BY Kim J S Wi SG 2005. Effects of in Planta gamma-irradiation on growth, photosynthesis, and antioxidative capacity of red pepper (Capsicum annuum L.) plants. J. Plant Biol. 48: 47-56.

Kumari R and Singh Y 1996. Effect of gamma rays and EMS on seed germination and plant survival of Pisum sativum L. and Lens culinaris Medic. Neo Bot. 4: 25-29.

Le-Docte A 1927. Commercial determination of sugar beet in the beet roots using Sachs Le-Docte process. Intern. Sugar J. 29: 488-492.

Makhlouf BSI and Khalil SR 2017. Improvement of yield and quality of sugar beet sown at two dates by methanol and boron application. Minufia J.Plant Prod. 2: 305-324.

Mehran S and S Samad 2013. Study of potassium and nitrogen fertilizer levels on the yield of sugar beet in jolge cultivar. J. Novel Appl. Sci, 2-4: 94-100. 
Page A L RH Miller and DR Keeney 1982. Methods of Chemical Analysis. Part2: Chemical and Microbiological properties (Second Edition). Amirican Socity of Agronomy, Inc. and Sci. Soc. Of America , Inc. Publisshers. , Madison, Wisconsin USA. 2: 1159.

Qotob MA, Nasef MA, Elhakim HKA, Shaker OG, Habashy NR and Abdelhamid IA 2019.Integrated effect of plant growth regulators with boron sources on some biological parameters of sugar beet Bio Rxiv preprint doi: https://doi.org/10.1101/839068. This version posted November 11, 2019. The copyright holder for this Preprint (which was not certified by peer review) is the author/funder. It is made available under a CC-BY-NC-ND 4.0 International license.

Tisdale SL, Nelson WL and Beaton JD 1985. Soil fertility and fertilizer. (4 ${ }^{\text {th }}$ edn), Macmillan Publishing. CoNew York. Vincent L 2010. Effect of boron fertilizer on sugar beet grown on fruit field sand soil. Iowa State Research Farm Progress Reports. 373. http://lib.dr.iastate.edu/farms_reports/373

Wang XG, Hua ZX, Hong JIJ, Shan LC, Qiu CDW, Qiu CY and Yan Y H 2015. Effects of potassium deficiency on photosynthesis and photoprotection mechanisms in soybean (Glycinemax (L.) Merr.). J Integra. Agric. 14, 856-863.

Wi SG, Chung, BY, Kim JH, Baek MH, Yang DH, Lee JW and Kim JS 2005. Ultrastructural changes of cell organelles in Arabidopsis stem after gamma irradiation. J. Plant Biol. 48: 195-200.

(Manuscript received on10 October, 2020; revised on 10 September, 2021) 